\title{
VIABILITY OF THE SEED OF LODGEPOLE PINE AFTER 20 YEARS IN ARTIFICIAL STORAGE
}

BY D. I. CROSSLEY

Graduating from the University of Toronto in 1935, Des. Crossley spent until 1940 with the Forest Nursery Station at Indian Head, Saskatchewan. He was engaged in the planning and establishment of field shelterbelt projects which were being investigated as a means of ameliorating the effects of drought under dry farming conditions. During this period he obtained a M.Sc. at the University of Minnesota. Following war service he joined the Department of Resources and Development in 1945 and went to the Alberta District Office to engage in silvicultural research. He serves at present as the Senior Research Officer at that point.

\section{$A B S T R A C T$}

Lodgepole pine bears its seed crop in cones that remain unopened on the tree for many years. Viability apparently remains unimpaired for a long period under these natural yet specific conditions. This paper reports similar high viability of extracted seed stored for 20 years under very haphazard artificial conditions, and compares it with the results obtained from similarly stored white spruce seed.

It has long been recognized that the seed of the serotinously coned lodgepole pine, Pinus contorta Dougl. var latifolia Engelm. remains viable for many years under natural storage conditions on the tree. Clements (2), after a rather exhaustive series of tests, states that there appeared to be little loss in viability of seeds from cones up to 25 years of age, and he relates instances of 45-year-uld seed and even 75 -year-old seed that germinated. The seed manual published by the Forest Service, U.S.D.A. (1) states that lodgepole pine seed may remain viable in storage on the tree for 30 years or more. On the other hand, it has never been considered possible to store seed artificially for such long periods of time. The same seed manual, in a tabulation of seed viability, suggests that lodgepole pine seed should only be stored under sealed conditions. Under ordinary temperatures a life of five years can be expected; when storage temperatures between $32^{\circ}$ and $41^{\circ} \mathrm{F}$ are maintained a life of seven years or longer is suggested. Similarly it is stated that spruce seed, kept in sealed containers under controlled temperature conditions, can be expected to retain its viability unimpaired for 10 or more years. Crossley and Skov (3) report a test of white spruce seed stored in a sealed container for 13 years under uncontrolled temperatures that resulted in 53 per cent apparent germination.

An unusual opportunity recently presented itself to test the viability of lodgepole pine seed that had been stored under very haphazard conditions for a period of 19 . to 20 years, and to compare it with the viability of white spruce seed that had been stored under identical conditions for the same period of time.

The lodgepole pine seed used in the study was collected in the Cypress Hills Provincial Forest, Saskatchewan, in 1934. No special care was given the extracted seed, and it was stored in an unsealed fish fry can in a room at

Submitted for Publication on January 3, 1955. 
the Prince Albert extraction plant under normal conditions of temperature and humidity. The room was unheated both winter and summer. The source of the white spruce seed is not known, but it was mixed with the pine seed for some now-forgotten reason and, therefore, has experienced identical storage conditions. It is of interest to note that the humidity in the storage can must have varied considerably through the years because, 19 years after storage commenced, the seed in the bottom 3 or 4 inches settled into a mass too solid to pour out when the can was inverted. This information, together with germination test data, was brought to the attention of the author in $1953^{x}$.

In the initial germination test ${ }^{2}$ no pretreatment was given the seed. The tests were conducted on random samples in 8 lots of 50 seeds on moist blotters. During the daylight hours $(8.30$ a.m. to 5.00 p.m.) the samples were placed in a Copenhagen tank germinator at $30^{\circ} \mathrm{C}$ under fluorescent light of approximately 100 -foot candles. For the remainder of each 24-hour-period they were placed in a constant-temperature room at $20^{\circ} \mathrm{C}$ under ordinary light. The results obtained are presented in the following table:

TABLE 1

First Apparent ${ }^{1}$ Germination Test of Lots of 50 Lodgerole Pine Seeds After 19 Years Storage

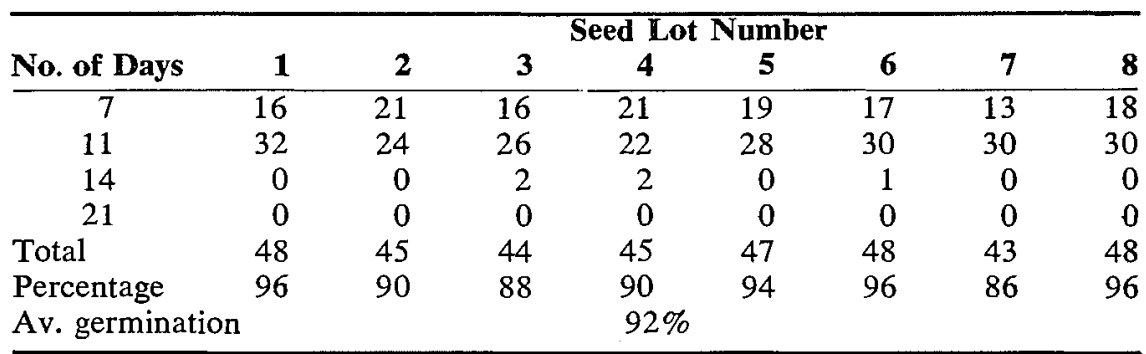

${ }^{1}$ Apparent germination is based on the total number of seeds used in the test regardless of their condition.

No details are available for the spruce seed tests other than the fact that they were run for 28 days and the germination percentage was 0.25 .

When the results of these tests were drawn to our attention, they were considered so amazing that a sample of the seed was requested in order that an attempt might be made to confirm them. In the meantime the seed had laid in a sealed envelope in an office drawer for an additional six months.

Previous studies had indicated that excellent germination results could be obtained with old white spruce seed by pre-chilling it in water (3), and it was therefore decided to adopt this method in the second series of germination tests. Five lots of 100 seeds of both pine and spruce were cold-soaked in water at $2^{\circ} \mathrm{C}$ for 21 days, following which they were placed between moist blotters

\footnotetext{
${ }^{\text {I Pertinent }}$ collection and storage information supplied by C. R. Christie, Senior Forester, Department of Natural Resources, Province of Saskatchewan.

${ }^{2}$ Initial germination test data supplied by J. S. Rowe, Forest Engineer, Forestry Branch, Department of Northern Affairs and National Resources.
} 
in a dark germination room at $20^{\circ} \mathrm{C}$. In spite of pregermination treatment and a different germination procedure from the first test, no signs of life were evident in the spruce seed. The results for lodgepole pine are presented in the following table:

TABLE 2

Second Apparent Germination Test of Lots of 100 Lodgepole Pine SEEDS After 191/2 YeArs IN STORAge

\begin{tabular}{lrrrrr}
\hline No. of Days & $\mathbf{1}$ & $\mathbf{2}$ & $\mathbf{3}$ & $\mathbf{4}$ & $\mathbf{5}$ \\
\hline 5 & 5 & 3 & 19 & 4 & $\mathbf{9}$ \\
10 & 3 & 5 & 3 & 3 & 2 \\
14 & 7 & 9 & $\mathbf{1 8}$ & 8 & $\mathbf{9}$ \\
21 & $\mathbf{1 8}$ & 19 & $\mathbf{1 1}$ & 13 & 7 \\
28 & 3 & 4 & 2 & 4 & 7 \\
35 & 1 & 0 & 2 & $\mathbf{1}$ & 3 \\
Total & 37 & 40 & 55 & 33 & 37 \\
Av. germination & & $40.4 \%$ & & & \\
\hline
\end{tabular}

The reduction in germination of the pine seed when compared with the first test was disturbing, and it was decided to run a third test using a procedure recommended by the Forest Seed Committee of the International Seed Testing Association, which was very similar to the procedure used in the original test. It was not until six months later that this test was undertaken, and in the meantime the seed sample was stored in a stoppered vial at room temperature.

Four lots of 100 randomly selected seeds were placed on moistened blotters in a Jacobsen germinator under natural light. During the daytime the temperature was maintained at $30^{\circ} \mathrm{C}$, and at night $20^{\circ} \mathrm{C}$. Once again the spruce seed showed no signs of life; after testing in 3 different ways the similarity of results indicates that it is no longer viable. The results for lodgepole pine are presented in the following table:

TABLE 3

Third Apparent Germination Test of Lots of 100 Lodgepole Pine Seeds AFTER 20 YEARS IN STORAGE

\begin{tabular}{lrrrr}
\hline No. of Days & $\mathbf{1}$ & Seed Lot Number & $\mathbf{3}$ & $\mathbf{4}$ \\
\hline 7 & 69 & 68 & 70 & 67 \\
14 & 18 & 6 & 13 & $\mathbf{6}$ \\
21 & 2 & 1 & 1 & 0 \\
28 & 0 & 0 & 0 & 0 \\
Total & 89 & 75 & 84 & 73 \\
Av. germination & & $80.2 \%$ & & \\
\hline
\end{tabular}

The third test on the pine seed confirms the original results, and suggests that the pre-chilling of seed in the second test was responsible for the depressed viability experienced at that time. 
From this series of tests it is apparent that:

1. Lodgepole pine seed can be stored under very haphazard conditions for a great number of years without loss of viability, but white spruce seed cannot.

2. Under suitable, and certainly not restrictive, conditions a 14-day germination test is sufficient to ascertain the viability of lodgepole pine seed.

3. The pre-chilling treatment previously found effective in the preparation of white spruce seed for germination tests was unsuited to lodgepole pine seed under similar testing procedures.

\section{REFERENCES}

1. ANONYMOUS. Woody Plant Seed Manual. Misc. Pub. No. 654, Forest Service U.S.D.A. 1948. 2. CLEMENTS, F. E., The Life History of Lodgepole Pine Burn Forests. Bull. 79, Forest Service, U.S.D.A. 1910.

3. CROSSLEY, D. I. AND SKOV, L. Cold Soaking as a Pre-Germination Treatment for White Spruce Seed. Silvicultural Leaflet No. 59, Div, of Forest Research, Forestry Branch, Dept. of Resources and Development, 1951. 